\title{
Parental self-regulation, emotional regulation and temperament: Implications for intervention
}

\author{
Autorregulação parental, regulação emocional e \\ temperamento: implicações para a intervenção
}

\author{
Luísa BARROS 1 \\ Ana Rita GOES ${ }^{1}$ \\ Ana Isabel PEREIRA ${ }^{1}$
}

\begin{abstract}
This work presents a theoretical and integrative review about parental self-regulation and emotional regulation processes, and its connections with parental coping and temperament. Parents' adaptation requires the ability to regulate their own behavior in reaction to their perception and interpretation of the child's behavior. These self-regulation processes are often intertwined with intense emotions that need to be regulated. Parenting attitudes and behaviors cannot be fully understood without considering the parents' emotional dysregulation and their emotional regulation strategies. However, only few studies focus the effects of parents' emotional regulation strategies on the parenting behavior. Experiential avoidance and overprotection are discussed as extreme cases of parental emotional regulation strategies that may have particularly detrimental effects in childrearing. The authors propose that, although the main parenting interventions already use a self-regulation approach, specific training in adaptive emotional regulation strategies should be included in these programs.
\end{abstract}

Keywords: Emotional regulation; Parenting; Self regulation; Temperament.

\section{Resumo}

Este trabalho apresenta uma revisão teórica integrativa dos processos de autorregulação e de regulação emocional parentais e da relação destes conceitos com o coping e o temperamento dos pais. A adaptação parental requer capacidade para regular o comportamento em reação à percepção do comportamento do filho. Estes processos de autorregulação estão frequentemente interligados com emoções intensas que precisam ser reguladas. Os comportamentos parentais não podem ser totalmente compreendidos sem se considerar a desregulação emocional e as estratégias de regulação emocional dos pais. No entanto, poucos trabalhos estudaram os efeitos das estratégias de regulação emocional no comportamento parental. O evitamento experiencial e a superproteção são apresentados como casos extremos de estratégias de regulação emocional parental que podem ter efeitos negativos na educação das crianças. As autoras propõem que, embora os principais modelos de intervenção parental usem uma abordagem de autorregulação, o treino específico em estratégias de regulação emocional adaptativas devem integrar estes programas.

Palavras-chave: Regulação Emocional; Parentalidade; Autorregulação; Temperamento.

$\nabla \nabla \nabla$

${ }^{1}$ Universidade de Lisboa, Faculdade de Psicologia, Pós-Graduação em Psicologia Clínica e da Saúde. Alameda da Universidade, 1649-013, Lisboa, Portugal. Correspondência para/Correspondence to: L. BARROS. E-mail: <lbarros@psicologia.ulisboa.pt>. 
Parenting involves the childrearing processes that parents undertake to promote and support their children's development and wellbeing. The relationship between parenting and children's development and adaptation has been studied using different approaches and methodologies. Evidence from epidemiological, correlational and experimental studies shows that parenting has a major influence on children's development (Collins, Maccoby, Steinberg, Hetherington, \& Bornstein, 2000). Previous studies indicate that family risk factors such as ineffective parenting (e.g., harsh discipline, low parent involvement and low monitoring) are powerful early predictors for the development and maintenance of behavioral and emotional problems in children and adolescents (Patterson, 1982; Teti \& Candelaria, 2002).

Although parenting studies have been developing for more than four decades, this literature focused mostly on global parental variables (such as parenting styles, parental stress, parental psychopathology) and particularly emphasized child behavior or child development as outcomes (Belsky \& Jafee, 2006). Parental cognition, beliefs, attributions and problem-solving, and its impact in childrearing behaviors and in children's development, have been the focus of less attention (Bugental \& Johnston, 2000; Siegel, 1985), nevertheless demonstrating how these cognitive dimensions and processes can influence both the macro and micro processes that occur in parentchild interaction and the child outcomes. Parents' emotional processes have been less studied, except in what concerns the impact of disturbed emotional states, such as anxiety and depression, on child development and adaptation (Cheron, Ehrenreich, \& Pincus, 2009; McLeod, Weisz, \& Wood, 2007; McLeod, Wood, \& Weisz, 2007).

\section{- Parental adaptation and self-regulation \\ Parental adaptation to childrearing demands requires the parents' ability to regulate their own behavior in reaction to their perception and interpretation of the child's behavior, while also \\ 296 facing many other challenges from their professional}

and relational adult life. As such, parental adaptation can be conceptualized as involving a dialectical relationship between parents' efforts to regulate their own behavior (self-regulation), and their attempts to regulate their child's behavior, health and development (parenting tasks). The first is an intimate and individual process while the latter is interpersonal and transactional (Cheron et al., 2009), but each one influences the other.

The parent's actions to regulate their children's behavior have been the focus of much research, mainly through the identification of different parenting strategies and actions, or different parental styles, and exploring the impact of these dimensions on children's development and adaptation (Gutman \& Feinstein, 2010; Maccoby, 2000; Pereira, Canavarro, Cardoso, \& Mendonça, 2009). Meanwhile, parents' own self-regulation processes have been less studied. Nevertheless, most parental interventions today claim the need to improve parental self-regulation skills and competencies (Sanders, 2008; Sanders \& Mazzucchelli, 2013).

Understanding parental adaptation as a selfregulation process is especially critical in situations where there are extra demands due to the child's characteristics such as difficult temperament, developmental problems, psychopathology or chronic illness, or to the family and social context, such as family transitions, bereavement or economic crisis. However, parental self-regulation is also relevant in daily childrearing interactions where parents have to anticipate, identify, recognize and solve a multitude of educational and health problems, often in a highly emotional context (Barros, 2015).

Self-regulation refers to the self's capacity to alter its behaviors in accordance to some standards, ideals or goals derived from internal or societal expectations (Baumeister \& Vohs, 2007). Parental self-regulation requires establishing educational goals and values, recognizing the need to use a plan or change usual behavioral patterns, planning, solving unexpected problems or overcoming barriers and monitoring theirs and their children's behavior (Sanders, 2008). According to Bandura 
(1991; 1997), most human behavior is purposive and regulated by the person's own influence, which includes sub-processes of self-monitoring (self-diagnostic and self-motivation), judgments, (evaluation of owns behavior against personal objectives and in the context of specific environmental circumstances, affective reactions and self-efficacy attributions) and self-reactions (thought, emotion and behavior). These self-regulation processes play an important role in motivation, delay of gratification and emotional expression, all part of the parenting role (Eisenberg, Fabes, \& Guthrie, 1997).

Karoly (1993) stated that the transactions involved in these self-regulation efforts include the modulation of thought, affect, attention and behavior, both through deliberate and intentional as well as automatic processes and metaskills. Although most parental behavior is rather automatic, these self-regulation processes are initiated when routinized activities and interactions are impeached or interrupted by a barrier, or when the activities directed towards an objective become salient due to a new concern or challenge (Karoly, 1993).

Applying the self-regulation conceptualization to the parenting processes, Sanders and Mazzucchelli (2013) defined a sequence of five stages: 1) self-determination of parental objectives, which may involve recognizing the need to change; 2) self-monitoring; 3 ) implementing and adapting plans; 4) self-evaluation against specific objectives; and 5) self-reinforcing.

Self-regulation is a key process in understanding what motivates parents to get involved in directing and changing their own behavior in order to produce changes in their children's behavioral, developmental and health outcomes. The cognitive dimension of this process has been repeatedly emphasized. For instance, parental beliefs about developmental tasks or about educational strategies and their expectations may affect the establishment of their educational objectives at each developmental stage, whereas their educational theories can affect the selection of strategies to reach these objectives (Gottman,
Katz, \& Hooven, 1996). Parental concerns are key processes in the identification/recognition of behavioral or health problems (Glascoe, 2003) and influence parents' engagement in change efforts or in their search for professional help (Brazelton, 1994). Parental expectations are a relevant dimension in parents' choice of developmentally adequate educational goals and in the choice of sensitive and positive parenting strategies (Sanders, 2008). Parental self-efficacy play an important role in the motivation-action loop, as high self-efficacy facilitates parents' drive to plan and implement educational changes, and the results of these actions will reinforce or decrease parents' attributions of selfefficacy. Self-efficacy is defined as an attribution or cognition, critical to the maintenance of parents' motivation to regulate their parenting, but is undeniably associated with emotionality (Bandura, 1991).

In fact, the whole process of self-regulation and motivation triggers intense positive emotions related to the definition and attainment of selfchallenges. Parenting may bring about multiple opportunities to experience positive emotions such as happiness, pride or joy. The positive role of emotions in decision making and problem solving (Campos, Mumme, Kermoian, \& R. G. Campos, 1994) and in self-regulation (Bandura, 1991) has been emphasized. The view of emotions as mechanisms of adaptation that help us identify what is detrimental or helpful to our well-being and general functioning (Lazarus, 1991) has prevailed in the last decades (Bariola, Gullone, \& Hughes, 2011).

On the other hand, parents often report complex negative emotions in response to their child's problems, including guilt, shame, depression, hopelessness, anger, and anxiety, which leads parents to embark in a process of emotional regulation that will result in a more or less controlled expression of these emotions and in different courses of action.

When people are involved in self-regulation, they often face situations that may arouse intense emotions, making processes of self-regulation closely connected with processes of Emotional Regulation (ER) (Koole, 2009). As such, parenting 
attitudes and behaviors cannot be fully understood without considering parents' ER strategies, as a critical component of their self-regulation processes.

\section{Emotional regulation}

Emotional regulation is the ability to respond to the ongoing demands of experience with emotions that may be moderated, inhibited, intensified or maintained according to the person's individual goals. These ER processes interact with the overall self-regulation and motivational processes (Gross, 1998).

According to the process model of Gross and Thompson (2007) emotional regulation involves extrinsic and intrinsic processes of monitoring, evaluating, and modifying the emotional reactions. It includes a mix of deliberate and more automatic processes, in a continuum from conscious, effortful and controlled regulation to unconscious, effortless and automatic regulation, with these latter processes being much more difficult to assess (Thompson, 1994).
Several strategies can be used alone or in combination to regulate emotions (Gross \& John, 2003) along this process model (Table 1). Antecedent-focused strategies occur before an emotional response is fully generated and influence the entire emotion-generative process. Responsefocused strategies occurr after an emotional response is fully generated, and as such its impact is more restrict. As they occur later in the temporal process, they require more effort in controlling the emotional response.

Although high levels of emotional regulation have been associated with social competence (Fabes et al., 1999), studies with clinical and non-clinical samples showed that some strategies are more adequate and effective than others (Bandura, Caprara, Barbaranelli, Gerbino, \& Pastorelli, 2003; Gross \& John, 2003). The efficacy of antecedentfocused strategies has received more attention than response modulation, mainly in studies relating emotional regulation to psychopathology (Koole, 2009).

According to the process model (Gross, 1998), ER strategies operate sequentially. Firstly, the anticipation of an undesirable emotional outcome

Table 1

Emotional Regulation Strategies (adapted from Gross \& John, 2003)

\begin{tabular}{|c|c|}
\hline & Antecedent-Focused Strategies \\
\hline Situation selection & Choosing to avoid or approach an emotionally relevant situation to regulate emotions. \\
\hline Situation modification & $\begin{array}{l}\text { Efforts to modify a situation so as to change its emotional impact. It includes altering one's external, } \\
\text { physical or social environment. }\end{array}$ \\
\hline \multirow[t]{5}{*}{ Attentional deployment } & Directing one's attention towards or away from an emotional situation. It may include: \\
\hline & a) Distraction, or diverting one's attention away from an emotional stimulus and towards other content. \\
\hline & $\begin{array}{l}\text { b) Rumination, or passive and repetitive focusing of one's attention on one's symptoms of distress and the } \\
\text { causes and consequences of these symptoms. }\end{array}$ \\
\hline & $\begin{array}{l}\text { c) Worry, or directing attention to thoughts and images concerned with potentially negative events in the } \\
\text { future. }\end{array}$ \\
\hline & d) Thought suppression, or the efforts to stop one's attention from specific thoughts and mental images. \\
\hline \multirow[t]{5}{*}{ Cognitive change } & Changing how one appraises a situation so as to alter its emotional meaning. May include: \\
\hline & $\begin{array}{l}\text { a) Reappraisal, involving reinterpreting the meaning of an event so as to alter its emotional impact by } \\
\text { reducing the emotional response. }\end{array}$ \\
\hline & $\begin{array}{l}\text { b) Distancing, taking on an independent, third-person perspective when evaluating an emotional event, } \\
\text { facilitating the emotional processing of negative stimuli and reducing emotional activation. }\end{array}$ \\
\hline & c) Humor, positive good-natured humor, which facilitates the downregulation of negative emotions. \\
\hline & Response-focused strategies \\
\hline Response modulation & Attempting to directly manipulate the experiential, behavioral, and physiological expression of emotions. \\
\hline
\end{tabular}


may lead to modifying or selecting the situation. Modifying a situation by creating concrete conditions to make the situation more approachable may be effective, although sometimes difficult to implement. On the other hand, selecting situations can be less adaptive, as adequately deciding which relevant situations to approach or to avoid is difficult (Loewenstein, 2007) and anxious persons tend to make excessive use of this avoidant strategy (Wells \& Papageorgiou, 1998). The second stage includes attentional deployment strategies, such as distraction, which may be very effective in limiting the impact of high-intensity emotional content without avoiding the situation, mainly in highly emotional situations (Sheppes, Scheibe, Suri, \& Gross, 2011); worry, that may be effective as it can involve problem solving, although prolonged worry is considered maladaptive (Campbell-Sills \& Barlow, 2007) and thought suppression that may provide temporary relief, but also lead to the paradoxical emergence of more unwanted thoughts (Wegner \& Zanakos, 1994), as it happens in obsessivecompulsive disorders (Purdon, 2004). When people cannot avoid paying attention to a stimulus that may arouse unwanted emotions, a third type of strategy is possible. Cognitive change includes some of the most elaborate and effective strategies, such as reappraisal, distancing, and humor to change the subjective meaning of the situation. Individuals tend to recur to cognitive change when facing stimuli of low negative emotional intensity because these stimuli are relatively easy to appraise and process (Scheppes et al., 2011), as opposed to more intense stimuli that are associated with a tendency to use avoidant behaviors. Finally, a fourth type of strategies may be activated, involving response modulation, including inhibition or exaggeration of spontaneous emotional expressions, but also controlled breathing and progressive muscle relaxation (Koole, 2009). Research has been mostly restricted to expressive suppression, generally considered a maladaptive strategy, associated with more disturbance and requiring high mobilization of cognitive resources (John \& Gross, 2004).

Nevertheless, the distinction between effective and ineffective strategies of ER needs to be careful. ER adequacy may depend on the context and the frequency of its use. More than the specific strategy, it is the ability to use different ER strategies with flexibility that characterizes healthy adaptation (Cole, Michel, \& Teti, 2004; Gratz \& Roemer, 2004). Avoiding a particularly distressing situation may be helpful if this strategy frees the needed inner resources to actively cope with other, less distressing but more modifiable, parallel situations. For instance, parents of very ill children sometimes dampen their emotional reaction to the diagnostic, or transform its meaning, and concomitantly direct their attention to help their child being more comfortable. On the other hand, avoidance may impeach parents' from dealing with educational problems that could be otherwise solved or minimized, such as when parents repeatedly avoid meeting with a teacher that will alert them for their child's learning difficulties or behavioral problems.

Moreover, particular care is needed when applying the individual ER strategies, mostly studied as private experiences in laboratory or clinical contexts, to the parenting context, where these processes occur in interpersonal and transactional contexts. According to Cheron et al. (2009) this is a uniquely private process, yet enacted through specific parent child interactions in the parenting context.

Emotion regulatory strategies may be effective in downgrading negative emotions aroused by the recognition of a child's misbehavior, disturbance or illness, and as such, diminishing the parents' suffering, but nonetheless be less effective because these strategies impeach parents from searching for effective solutions to their child's problems (Thompson \& Calkins, 1996). For instance, cognitive reappraisal is a very effective approach to regulate intense negative emotions and can be counterproductive when these negative emotions are aroused by situations that may need a concrete solution, as this strategy may decrease the parents' motivation to directly address the problem (Troy, Shallcross, \& Mauss, 2013).

There are only a few studies directed to the effect of parents' ER strategies on parenting behavior. Dix and Yan (2014) observed that 
depressed mothers heightened sensitivity to the child's aversive inputs lead them to direct their behavior towards the minimization of their own negative affect and not to the satisfaction of the children's needs.

\section{Emotion regulation and coping}

The previous discussion about emotional regulation strategies may suggest the existence of some overlapping between the concepts of emotional regulation and coping. Although it seems forceful to relate the concepts of coping and ER in the context of parenting studies, whether these constructs are similar or distinct concepts and mainly, how they relate to one another, has been the focus of much debate.

According to Gross and Thompson (2007), ER and coping are instances integrated in the broader construct of affect regulation, but are different constructs. These authors distinguish coping from ER both by the predominant focus of coping on decreasing negative affect, and by its emphasis on much larger periods of time. On the contrary, Kopp (1989) argues that ER is a particular case of coping, consistent with the earlier Lazarus and Folkman (1984) dual perspective of coping as problem-focused or emotional focused. Others agree that "many forms of coping are very similar to types of regulation discussed in the ER literature" (Eisenberg et al., 1997, p.288), or that all strategies of emotional regulation can be considered ways of coping (Bridges \& Grolnick 1995). Meanwhile other authors have maintain some assimilation between these two constructs as they use coping strategies measures to assess ER (Contreras, Kerns, Weimer, Gentzler, \& Tomich, 2000).

However, there are some relevant distinctions that may be helpful in guiding the research process in this domain. On one hand, coping does not rely exclusively on emotional regulation strategies, as much coping is problem focused and oriented towards problem solving. On the other hand, and following Skinner's definition of coping as action regulation under stress (Skinner, 300 1999), coping refers to only a subset of self- regulatory processes - those that take place under stressful circumstances. Finally, in a more integrative view, Metcalfe and Mischel (1999) suggest that an individual response reflects a balance between coping and emotion reactivity and regulation, such that "unregulated involuntary responses could reflect a strong stress reaction and/or a weak (immature or disabled) regulatory system, whereas volitional coping attempts reflect a weak stress response and/or a well-developed action regulation system" (Skinner \& Zimmer-Gembeck, 2007, p.124).

\section{Parental emotional dysregulation}

As already mentioned, there is a paucity of empirical studies about the consequences of parental self-regulation, or about parents' use of emotional-regulation strategies, to their parenting behaviors. However, some studies have highlighted the negative consequences of poor parental emotional self-regulation, or emotional dysregulation, translated in inappropriate emotional expression, which may, in turn, contribute to harsh or punitive discipline strategies or in intense anger, hostility or frustration externalization (Dix, 1991). For instance, the repeated and overt expression of combined parental depression and hostility (Reeb, Conger, \& Wu, 2010), or depression and anxiety (Kane \& Garber, 2004), were associated both with externalizing and internalizing children's problems. Carrère and Bowie (2011) showed that parents with difficulties in regulating the expression of hostility had children with more externalizing problems. On the other hand, difficulties in maternal selfregulation, translated in the use of maladaptive externalizing strategies, (throwing things, self-harm, eating, fighting, or sexual behaviors), were associated with less emotional availability and responsiveness to the child (Kim, 2010). Patterson (1982), in his classical work on family coercion, highlighted how dysfunctional patterns of parentchild interaction may result from ineffective attempts of both adult and child to regulate their negative emotionality, or how parents revert to negative and physically abusive behaviors when they are angry or emotionally out of control. 
In many of these situations, it is possible to recognize the absence or failure of self-regulation efforts, which impacts on thoughts, actions, and interactions (Schechter \& Willheim, 2009). Individuals who are emotionally deregulated exhibit patterns of responding in which there is a mismatch between their goals, responses, and modes of expression, and the demands of the social environment (Bandura, Caprara, Barbaranelli, Gerbino \& Pastorelli, 2003). In these situations, more than using ineffective strategies, they mostly fail to regulate their own emotions, externalizing in an intensive and uncontrolled way their feelings of hostility, aggression or frustration through harsh discipline or overt expression of contempt or depression, disillusion or despair. Harsh and impulsive discipline strategies have been characterized as an over reactive strategy (Bugental \& Happaney, 2004) and have been related to parents' physiological hyper reactivity to the child signals (McCanne \& Hagstrom, 1997) and to a higher probability of child abuse and maltreatment (Scannapieco \& Connell-Carrick, 2005).

\section{Experiential avoidance}

A very different process may occur when parents react to intense emotions aroused in the interaction with their children with experiential avoidance (Hayes, Wilson, Gifford, Follette, \& Strosahl, 1996). This occurs when a person feels incapable of being exposed to aversive or anxious situations and acts in order to change the form or frequency of these experiences even when these actions cause them behavioral harm (Hayes, Luoma, Bond, Masuda, \& Lillis, 2006). When a parent faces the need to choose between controlling their own negative emotionality and the aim of regulating their children's negative emotions or behavior, the objective of downgrading the parents' negative emotions becomes dominant. As such, a parent may use several cognitive and behavioral strategies to avoid the emotional experience. These avoidant parental strategies have been linked to an also avoidant coping style (Eisenberg, Fabes, \& Murphy, 1996). But, in some extreme cases, parents may be reverting to experiential avoidance, as a systematic unwillingness to tolerate aversive private experiences. According to Wolgast, Lundh, and Viborg (2013) experiential avoidance is not a strategy of emotional regulation, as the ones previously described, but rather an emotion regulatory function of several strategies. Other authors have characterized experiential avoidance as a psychological vulnerability for anxiety disorders (Kashdana, Barrios, Forsyth, \& Steger, 2006).

Some parents may systematically avoid situations that they anticipate can cause intense anxiety, depression, anger or frustration. The study of experiential avoidance in the context of parenting has been mostly restricted to the parental effects on children's anxiety disorders. Cheron et al. (2009) showed that parents who reported elevated levels of experiential avoidance also reported significantly higher levels of depression and anxiety and that these parents also report greater problems with their own anxiety and mood difficulties.

Although with scarce empirical evidence, parental overprotection and high control practices have been associated with ER difficulties and particularly with avoidant strategies (Tiwari et al., 2008). Parents' overprotection may be a personal emotional regulation strategy and even become a pattern of experiential avoidance. Parents may use situation selection and avoidance to impeach their children to confront new and challenging situations, thus controlling their own anxiety. Cheron et al. (2009) found that parents who reported high levels of experiential avoidance also reported high levels of control in the parenting context.

\section{Parental self-regulation and temperament}

Temperament is yet another parental dimension that much probably interacts with parental self-regulation. Defined as a set of individual differences in constitutionally based reactivity and self-regulation (Rothbart \& Derryberry, 1981), temperament has been proposed as a critical concept to the study of individual differences, allowing the use of process-oriented approaches, often lacking in more trait-oriented theories of 
personality (Rothbart, Ahadi, \& Evans, 2000). Thus, reactivity refers to individual differences in motor arousal, emotionality and orienting, while selfregulation is considered as a major constituent of the structure of temperament and refers to processes that moderate this reactivity (Rothbart, Ellis, \& Posner, 2004).

Parents' temperament has been associated with the self-regulatory processes parents use to regulate interaction with their children and select parental strategies they rely on to control their children's behavior (Putnam, Sanson, \& Rothbart, 2002). Parents' ER processes have strong temperamental bases but are also the product of experiences of conditioning and learning. Three developmentally stable, higher-order temperament factors are particularly relevant to ER. The first two of these negative emotionality and positive emotionality have consistently been implicated in depressive disorders in the form of heightened negative affect and diminished positive affect (Chorpita, Yim, Moffitt, Umemoto, \& Francis, 2000; Joiner, Catanzaro, \& Laurent, 1996). The third fundamental temperament factor, effortful control (Rothbart, Ellis, Rosario Rueda, \& Posner, 2003), allows one to suppress affect-driven motivational and behavioral tendencies in order to align behavior and achieve a conflicting goal. Although research in the domain of parental temperament is very scarce, one may speculate that, as a function of parental dimensions such as effortful control or negative emotionality, some parents will have more probability of being able to effectively use ER strategies and balance the need to regulate their emotions while choosing effective educational and discipline strategies. For instance, high maternal effortful control predicted the amount of time spent by the mother in everyday childcare, which in turn contributed to the increase in effortful control of the child measured at age 18 months (Bridget et al., 2009). Mothers, who were more sensitive in humor, emotion and physical sensations, and less compulsive, showed a higher oxytocin answer, which has been linked to maternal bonding behaviors (Strathearn, lyengar, Fonagy, \&

302 Kim, 2012). Cumberland-Li, Eisenberg, Champion,
Gershoff, and Fabes (2003) found that maternal dispositional emotionality and regulation influenced the emotional quality of their interactions with their children, which in turn influenced their children's emotional competence and adjustment. In particular, they reported that mothers high in negative emotionality tended to be relatively low on positive expressivity, which in turn predicted poorer psychosocial functioning on the part of the children.

Ben-Porath (2010) raises yet another interesting possibility. As there is evidence of hereditability in the temperamental self-regulation differences (Kagan, 1997), one may consider that parents with difficulties in ER will have more probability of having children also with more difficulties in affect regulation. This may lead to a negative feedback loop, whereby the child's emotional difficulties pose extra demands to an already temperamentally vulnerable parent (Patterson, Reid, \& Dishion, 1992)

\section{Clinical implications}

Parenting programs have identified the development of self-regulation as a critical dimension in effective interventions (Sanders \& Morawska, 2008), although the specific components of these change or whether changes in these mechanisms indeed form the basis for an effective parenting intervention is still largely unknown.

Failure in parents' self-regulation and ER processes may help to explain different problems in the parenting process. Parental emotional dysregulation may result in impulsive harsh discipline or in the externalizing of intense negative emotions during parent-child interactions. Some parents may fail to identify, recognize or accept the existence of children's problems, or may not get involved in the necessary problem-solving and change plans, because just thinking about the child's problem arouses intense negative emotions, which they are unable or unwilling to experience. As such, they may resort to ER strategies leading to experiential avoidance, like minimization of the problem, ignoring or averting attention, or selection of 
situations. Lack of adherence or low participation in children's psychological intervention or medical treatment may be associated with this experiential avoidance. Other parents may be overprotective of the child as a response to their own unregulated anxiety.

However, most parenting interventions do not include specific strategies directed to help parents with more difficulty in regulating their emotions. It seems important that parenting interventions, even when delivered in the group format, take in consideration individual differences and incorporate ER strategies training. Although these interventions have demonstrated very positive results with different populations, age groups and special conditions, some parents may need additional training in dealing with their own emotions and learning how to balance the regulation of their emotionality with the childcentered educational goals of parenting. Concomitantly, it is necessary to explore and address the high drop-out rate in these interventions (Heinrichs, Bertram, Kuschel, \& Hahlweg, 2005). Finally, although many parents may profit from parenting interventions and learn new skills, generalization of these skills to the natural environment may be an increased challenge for parents with more difficulty in ER (Ben-Porath, 2010).

More research on parents' self-regulation, and especially on the impact of emotional regulation strategies on parenting and discipline strategies, is needed. Additionally, it is necessary to examine if parenting interventions are actually promoting parental self-regulation and if parent's self-regulatory capacity is a potential predictor of change in parenting and/or child outcomes.

\section{References}

Bandura, A. (1991). Social cognitive theory of self-regulation. Organizational Behavior and Human Decision Processes, 50, 248-287.

Bandura, A. (1997). Self-efficacy: The exercise of control. New York: W.H. Freeman.

Bandura, A., Caprara, G. V., Barbaranelli, C., Gerbino, M. \& Pastorelli, C. (2003). Role of affective self- regulatory efficacy in diverse spheres of psychosocial functioning. Child Development, 74(3), 769-782. http://dx.doi.org/10.1111/1467-8624.00567

Bariola, E., Gullone, E., \& Hughes, E. K. (2011). Child and adolescent emotion regulation: The role of parental emotion regulation and expression. Clinical Child and Family Psychology Review, 14(2), 198-212.

Barros, L. (2015) Intervenção com pais: processo e fases de mudança. In A. I. Pereira, A. R. Goes, \& L. Barros (Eds.), Promoção da parentalidade positiva: intervenções psicológicas com pais de crianças e adolescentes. Lisboa: Coisas de Ler.

Baumeister, R. F., \& Vohs, K. D. (2007). SelfRegulation, ego depletion, and motivation. Social and Personality Psychology Compass, 1(1), 115-128.

Belsky, J., \& Jafee, S. R. (2006). The multiple determinants of parenting. In D. Cicchetti \& D. J. Cohen (Eds.), developmental psychopathology (Vol.3, pp.38-85). New York: John Wiley \& Sons.

Ben-Porath, D. D. (2010). Dialectical behavior therapy applied to parent skills training: Adjunctive treatment for parents with difficulties in affect regulation. Cognitive and Behavioral Practice, 17(4), 458-465.

Brazelton, T. B. (1994). Touchpoints: Opportunities for preventing problems in the parentchild relationship. Acta Paediatrica, 83(394), 35-39.

Bridges, L. J., \& Grolnick, W. S. (1995). The development of emotional self-regulation in infancy and early childhood. Social Development, 15, 185-211.

Bridgett, D. J., Gartstein, M. A., Putnam, S. P., McKay,T., Iddins, E., Robertson, C., ... Rittmueller, A. (2009). Maternal and contextual influences and the effect of temperament development during infancy on parenting in toddlerhood. Infant Behavior and Development, 32(1), 103-116. http://dx.doi.org/10.10 16/j.infbeh.2008.10.007

Bugental, D., \& Johnston, C. (2000). Parental and child cognitions in the context of the family. Annual Review of Psychology, 51(1), 314-344.

Bugental, D. B., \& Happaney, K. (2004). Predicting infant maltreatment in low-income families: The interactive effects of maternal attributions and child status at birth. Developmental Psychology, 40(2), 234-243.

Campbell-Sills, L., \& Barlow, D. H. (2007). Incorporating emotion regulation into conceptualizations and treatments of anxiety and mood disorders. In J. J. Gross (Ed.), Handbook of emotion regulation (pp.542-559). New York: Guilford Press.

Campos, J. J., Mumme, D. L., Kermoian, R., \& Campos, R. G. (1994). A functionalist perspective on the nature of emotion. Monographs of the Society for Research in Child Development, 59(23), 284-303.

Carrère, S., \& Bowie, S. H. (2011). Like parent, like child: Parent and child emotion dysregulation. Archives of 
Psychiatric Nursing, 26(3), 23-30. http://dx.doi.org/ 10.1016/j.apnu.2011.12.008

Cheron, D. M., Ehrenreich, J. T., \& Pincus, D. B. (2009). Assessment of parental experiential avoidance in a clinical sample of children with anxiety disorders. Child Psychiatry and Human Development, 40(3), 383-403.

Chorpita, B. F., Yim, L., Moffitt, C., Umemoto, L. A., \& Francis, S. E. (2000). Assessment of symptoms of DSMIV anxiety and depression in children: A revised child anxiety and depression scale. Behaviour Research and Therapy, 38(8), 835-855.

Cole, P. M., Michel, M. K., \& Teti, L. O. (1994). The development of emotion regulation and dysregulation: A clinical perspective. Monographs of the Society for Research in Child Development, 59(2-3), 73-102. http:// dx.doi.org/10.1111/j.1540-5834.1994.tb01278.x

Collins, W. A., Maccoby, E. E., Steinberg, L., Hetherington, E. M., \& Bornstein, M. H. (2000). Contemporary research on parenting: The case for nature and nurture. American Psychologist, 55(2), 218-232. http://dx.doi. org/10.1037//0003-066X.55.2.218

Contreras, J. M., Kerns, K. A., Weimer, B. L., Gentzler, A. L., \& Tomich, P. L. (2000). Emotion regulation as a mediator of associations between mother-child attachment and peer relationships in middle childhood. Journal of Family Psychology, 14(1), 111-24.

Cumberland-Li, A., Eisenberg, N., Champion, C., Gershoff, E., \& Fabes, R. A. (2003). The relation of parental emotionality and related dispositional traits to parental expression of emotion and children's social functioning. Motivation and Emotion, 27(1), 27-56.

Dix, T., \& Yan, N. (2014). Mothers' depressive symptoms and infant negative emotionality in the prediction of child adjustment at age 3: Testing the maternal reactivity and child vulnerability hypotheses. Development and Psychopathology, 26(1), 111-124.

Dix, T. (1991). The affective organization of parenting: Adaptive and maladaptative processes. Psychological Bulletin, 110(1), 3-25.

Eisenberg, N., Fabes, R. A., \& Murphy, B. C. (1996). Parents' reactions to children's negative emotions: Relations to children's social competence and comforting behavior. Child Development, 67(5), 2227-47.

Eisenberg, N., Fabes, R. A., \& Guthrie, I. K. (1997). Coping with stress: The roles of regulation and development. In S. A. Wolchik \& I. N. Sandler (Eds.), Handbook of children's coping: Linking theory and intervention (pp.41-70). New York, NY: Plenum.

Fabes, R. A., Eisenberg, N., Jones, S., Smith, M., Guthrie, I., Poulin, R., ... Friedman, J. (1999). Regulation, emotionality, and pre-schoolers' socially competent peer interactions. Child Development, 70(2), 432-442.

Glascoe, F. P. (2003). Parents' evaluation of developmental status: Do parents' concerns detect behavioral and emotional problems? Clinical Pediatrics, 42(2),133-139.
Gottman, J. M., Katz, L. F., \& Hooven, C. (1996). Parental meta-emotion philosophy and the emotional life of families: Theoretical models and preliminary data. Journal of Family Psychology, 10(3), 243-68.

Gratz, K. L., \& Roemer, L. (2004). Multidimensional assessment of emotion regulation and dysregulation: Development, factor structure, and initial validation of the difficulties in emotion regulation scale. Journal of Psychopathology and Behavioral Assessment, 26(1), 41-54.

Gross, J. J., \& Thompson, R. A. (2007). Emotion regulation: Conceptual foundations. In J. J. Gross (Ed.), Handbook of emotion regulation (pp.3-26). New York: Guilford Press.

Gross, J., \& John, O. (2003). Individual differences in two emotion regulation processes: Implications for affect, relationships, and well-being. Journal of Personality and Social Psychology, 85(2), 348-62. http://dx.doi. org/10.1037/0022-3514.85.2.348

Gross, J. J. (1998). The emerging field of emotion regulation: An integrative review. Review of General Psychology, 2(3), 271-299.

Gutman, L. M., \& Feinstein, L. (2010). Parenting behaviours and children's development from infancy to early childhood: Changes, continuities and contributions. Early Child Development and Care, 180(4), 535-556. http://dx.doi.org/10.1080/030044 30802113042

Hayes, S. C., Luoma, J., Bond, F., Masuda, A., \& Lillis, J. (2006). Acceptance and commitment therapy: Model, processes, and outcomes. Behaviour Research and Therapy, 44(1), 1-25.

Hayes, S. C., Wilson, K. G., Gifford, E. V., Follette, V. M., \& Strosahl, K. (1996). Experiential avoidance and behavioral disorders: A functional dimensional approach to diagnosis and treatment. Journal of Consulting and Clinical Psychology, 64(6), 1152-68. http://dx.doi.org/10.1037/0022-006X.64.6.1152

Heinrichs, N., Bertram, H., Kuschel, A., \& Hahlweg, K. (2005). Parent recruitment and retention in a universal prevention program for child behavior and emotional problems: Barriers to research and program participation. Prevention Science, 6(4), 275-286. http:// dx.doi.org/10.1007/s11121-005-0006-1

John, O. P., \& Gross, J. J. (2004). Healthy and unhealthy emotion regulation: Personality processes, individual differences, and life span development. Journal of Personality, 72(6), 1301-1333.

Joiner, T. E., Catanzaro, S. J., \& Laurent, J. (1996). Tripartite structure of positive and negative affect, depression, and anxiety in child and adolescent psychiatric inpatients. Journal of Abnormal Psychology, 105(3), 401-409.

Kagan, J. (1997). Temperament and the reactions to unfamiliarity. Child development, 68(1), 139-143. 
Kane, P., \& Garber, J. (2004). The relations among depression in fathers, children 's psychopathology, and father-child conflict: A meta-analysis. Clinical Psychology Review, 24(3), 339-360.

Karoly, P. (1993). Mechanisms of self-regulation: A systems view. Annual Review of Psychology, 44(1), 23-52.

Kashdana, T., Barrios, V., Forsyth, J. P., \& Steger, M. F. (2006). Experiential avoidance as a generalized psychological vulnerability: Comparisons with coping and emotion regulation strategies. Behaviour Research and Therapy, 44(1), 1301-1320.

Kim, B. R. (2010). Mothers' affect dysregulation, depressive symptoms, and emotional availability during mother-infant interaction (Unpublished master thesis). The Pennsylvania State University.

Koole, S. L. (2009). The psychology of emotion regulation. Cognition and Emotion, 23(1), 4-41.

Kopp, C. B. (1989). Regulation of distress and negative emotions: A developmental view. Developmental Psychology, 25(3), 343-354.

Lazarus, R. S. (1991). Emotion and adaptation. Oxford: Oxford University Press.

Lazarus, R. S., \& Folkman, S. (1984). Stress: Appraisal, and coping. New York: Springer Publishing Company.

Loewenstein, G. (2007). Affect regulation and affective forecasting. In J. J. Gross (Ed.), Handbook of emotion regulation (pp.180-203). New York: Guilford Press.

Maccoby, E. E. (2000). Parenting and its effects on children: On reading and misreading behavior genetics. Annual Review of Psychology, 51(1), 1-27. http://dx.doi.org/10.1146/annurev.psych.51.1.1

McCanne, T. R., \& Hagstrom, A. H. (1997). Physiological hyperreactivity to stressors in physical child abusers and individuals at risk for being physically abusive. Aggression and Violent Behavior, 1(4), 345-358.

McLeod, B. D., Weisz, J. R., \& Wood, J. J. (2007). Examining the association between parenting and childhood depression: A meta-analysis. Clinical Psychology Review, 27(8), 986-1003. http://dx.doi.org/ 10.1016/j.cpr.2007.03.001

McLeod, B. D., Wood, J. J., \& Weisz, J. R. (2007). Examining the association between parenting and childhood anxiety: A meta-analysis. Clinical Psychology Review, 27(2), 155-72. http://dx.doi.org/10.1016/ j.cpr.2006.09.002

Metcalfe, J., \& Mischel, W. (1999). A hot/cool-system analysis of delay of gratification: Dynamics of willpower. Psychological Review, 106(1), 3-19.

Patterson, G. R. (1982). Coercive family process. Eugene: Castalia.

Patterson, G. R., Reid, J. B., \& Dishion, T. J. (1992). Antisocial boys: A social interactional approach. Eugene: Castalia.
Pereira, A., Canavarro C., Cardoso M., \& Mendonça, D. (2009). Patterns of parental rearing styles and child behaviour problems among Portuguese school-aged children. Journal of Child and Family Studies, 18(4), 454-464.

Purdon, C. (2004). Empirical investigations of thought suppression in OCD. Journal of Behavior Therapy and Experimental Psychiatry, 35(2), 121-136.

Putnam, S. P., Sanson, A. V., \& Rothbart, M. K. (2002). Child temperament and parenting. In: M.Bornstein (Ed.), Handbook of parenting (Vol.1, pp.255-277). New York: Lawrence Erlbaum.

Reeb, B. T., Conger, K. J., \& Wu, E. Y. (2010). Paternal depressive symptoms and adolescent functioning: The moderating effect of gender and father hostility. Fathering, 8(1), 131-142.

Rothbart, M. K., \& Derryberry, D. (1981). Development of individual differences in temperament. Advances in Developmental Psychology, 1, 37-86.

Rothbart, M. K., Ahadi, S. A., \& Evans, D. E. (2000). Temperament and personality: Origins and outcomes. Journal of Personality and Social Psychology, 78(1), 122-135.

Rothbart, M. K., Ellis, L. K., \& Posner, M. I. (2004). Temperament and self-regulation. In: R.F. Baumeister \& K.D. Vohs (Eds.), Handbook of self-regulation: Research, theory, and applications (pp.357-370). New York: Guilford Press.

Rothbart, M. K., Ellis, L. K., Rosario Rueda, M., \& Posner, M. I. (2003). Developing mechanisms of temperamental effortful control. Journal of Personality, 71(6), 11131144.

Sanders, M. R. (2008). Triple P-Positive Parenting Program as a public health approach to strengthening parenting. Journal of Family Psychology, 22(4), 506-17. http:// dx.doi.org/10.1037/0893-3200.22.3.506

Sanders, M. R., \& Mazzucchelli, T. G. (2013). The promotion of self-regulation through parenting interventions. Clinical Child and Family Psychology Review, 16(1), 1-17.

Sanders, M. R., \& Morawska, A. (2008). Can changing parental knowledge, dysfunctional expectations and attributions, and emotion regulation improve outcomes for children? In R. E. Tremblay, M. Boivin, \& R. V. Peters (Eds.), Encyclopedia on Early Childhood Development. Montreal: Quebec. $2^{\text {nd }}$ ed. Retrivied October 15, 2014, from http://www.excellenceearlychildhood.ca/documents/Sanders-Moraws kaANGxp.pdf

Scannapieco, M., \& Connell-Carrick, K. (2005). Ecological and developmental perspective on child maltreatment. New York: Oxford University Press.

Schechter, D. S., \& Willheim, E. (2009). Disturbances of attachment and parental psychopathology in early childhood. Child and Adolescent Psychiatric Clinics of North America, 18(3), 665-686. 
Sheppes, G., Scheibe, S., Suri, G., \& Gross, J. J. (2011). Emotion-regulation choice. Psychological Science, 22(11), 1391-1396.

Siegel, I. (1985). Parental belief systems: The psychological consequences for children. Hillsdale: Lawrence Erlbaum.

Skinner, E. A. (1999). Action regulation, coping, and development. In J. B. Brandtstädter \& R. M. Lerner (Eds.), Action and self-development (pp.465-503). Thousand Oaks: Sage.

Skinner, E., \& Zimmer-Gembeck, M. (2007). The development of coping. Annual Review of Psychology, $58,119-144$.

Strathearn, L., lyengar, U., Fonagy, P., \& Kim, S. (2012). Maternal oxytocin response during mother-infant interaction: Associations with adult temperament. Hormones and Behavior, 61(3), 429-435.

Teti, D. M., \& Candelaria, M. A. (2002). Parenting competence. In: M.Bornstein (Ed.), Handbook of parenting (Vol.4, pp.149-180). New York: Lawrence Erlbaum.

Thompson, R. A. (1994). Emotion regulation: A theme in search of definition. Monographs for the Society for Research in Child Development, 59(2-3), 25-52.

Thompson, R. A., \& Calkins, S. D. (1996). The doubleedged sword: Emotional regulation for children at risk. Development and Psychopathology, 8(1), 163-182.
Tiwari, S., Podell, J. C., Martin, E. D., Mychailyszyn, M. P., Furr, J. M., \& Kendall, P. C. (2008). Experiential avoidance in the parenting of anxious youth: Theory, research, and future directions. Cognition and Emotion, 22(3), 480-496. http://dx.doi.org/10.1080/ 02699930801886599

Troy, A. S., Shallcross, A. J., \& Mauss, I. B. (2013). A person-by-situation approach to emotion regulation: Cognitive reappraisal can either help or hurt, depending on the context. Psychological Science, 24(12), 2505-2514. http://dx.doi.org/10.1177/095 6797613496434

Wegner, D. M., \& Zanakos, S. (1994). Chronic thought suppression. Journal of Personality, 62(4), 615-640.

Wells, A., \& Papageorgiou, C. (1998). Social phobia: Effects of external attention on anxiety, negative beliefs, and perspective taking. Behavior Therapy, 29(3), 357-370.

Wolgast, M., Lundh, L. G., \& Viborg, G. (2013). Experiential avoidance as an emotion regulatory function: An empirical analysis of experiential avoidance in relation to behavioral avoidance, cognitive reappraisal and response suppression. Cognitive Behaviour Therapy, 42(3), 224-232.

Received: December 15, 2014

Approved: January 12, 2015 